\title{
The Effect of Job Satisfaction, Workload and Job Stress on Turnover Intention at CV Sarana Komunikasi Indonesia
}

\author{
Tontowi \\ University of Sunan Giri, Faculty of Social and Political Science, Jl. Brigadier General Katamso II Waru \\ Sidoarjo, Surabaya
}

\begin{abstract}
This study aims to analyze the effect of job satisfaction, workload and job stress on turnover intention at CV Sarana Komunikasi Indonesia. The independent variables are job satisfaction, workload and job stress, while the dependent variable is employee turnover intention. The population is 320 employees. A total of 135 samples were selected by proportional random sampling technique. Data were collected by using a questionnaire that had been tested for validity and reliability. The data analysis technique used is multiple regressions. The results showed that variables job satisfaction, workload, and job stress simultaneously has a positive and significant effect on variable turnover intention. The $\mathrm{T}$ test shows that job satisfaction, workload and job stress partially have a significant effect on employee turnover intention variable.
\end{abstract}

Keywords: job satisfaction, workload, job stress, turnover intention.

DOI: $10.7176 /$ RHSS/11-22-09

Publication date: November $30^{\text {th }} 2021$

\section{INTRODUCTION}

Job satisfaction is very important for every worker. Job satisfaction is a reflection of one's feelings towards his job. "Job satisfaction is the key driver of morale, discipline, and employee performance in supporting the realization of company goals" (Hasibuan, 2014:203). Unsatisfied Employees will cause a workload so that employee will feel stressed.

Tarwaka (2015) stated that "Workload is a capacity or ability of workers with job demands that must be faced, considering that human work is mental and physical, then each has a different level of loading. Danang Sunyoto (2012: 64) stated that too much workload can cause stress. This can be caused by level of expertise demanded is too high, work speed may be too high, work volume may be too much and so on. Excessive workload can adversely affect employees and can cause stress.

Stress is a condition that cannot be avoided. Humans have many needs in their lives, but in fulfilling them, obstacles and obstacles will always accompany them. Sunyoto (2012: 61) stated that stress has different meanings for each individual. Workload and stress that are not handled properly can affect turnover intention.

Turnover intention refers to results of an individual's evaluation of continuation the relationship with organization and has not been manifested in definite actions to leave the organization. Data on CV Sarana Communication Indonesia shows a fairly high turnover rate of 54 employees in 2017. Based on above phenomenon, researchers are interested in further researching the effect of turnover intention, job satisfaction, workload, and job stress variables . Researchers consider it necessary to conduct a study to employees of CV Sarana Komunikasi Indonesia.

\section{LITERATURE REVIEW}

\section{Job satisfaction}

"Job satisfaction is a pleasant or unpleasant emotional state in which employees view their work. Job satisfaction reflects a person's feelings towards his job" (Handoko, 2014: 193). Job satisfaction is a reflection of a person's feelings towards his job. "Job satisfaction is the key to driving morale, discipline, and employee performance in supporting the realization of company goals". (Hasibuan, 2014:203).

It can be concluded that job satisfaction is an important issue that must be considered in relation to employee work productivity and dissatisfaction. It is often associated with high levels of worker demands and complaints.

\section{Workload}

Tarwaka (2015) stated that "Workload is a capacity or ability of workers with job demands that must be faced, considering that human work is mental and physical, then each has a different level of loading. The level of loading that is too high allows excessive use of energy to create overstress, on other hand, intensity of loading that is too low allows boredom and saturation or under stress. Therefore, it needs to strive for optimum level of loading intensity that exists between the two extreme limits.

Tarwaka (2011:106) stated that workload is "Something that arises from interaction between the demands of tasks of work environment which is used as a place of work, skills and perceptions of workers". Workload is sometimes defined operationally on factors such as the demands of task or the effort put into doing the job. 
According to Menpan in Dhini (2010:16), "the notion of workload is a collection or number of activities that must be completed by an organizational unit or position holder within a certain period of time". Thus the understanding of workload is a process carried out by a person in completing the tasks of a job or group of positions carried out under normal circumstances within a certain period of time owned by worker in completing his task, as well as the individual's own subjective view of work given to him.

\section{Job stress}

Mangkunegara (2013:157) stated that job stress was a feeling of pressure experienced by employees in dealing with work. This job stress can be seen from Symptom, including unstable emotions, feeling uneasy, being alone, having trouble sleeping, excessive smoking, anxiety, tension, nervousness, higher blood pressure, and digestive disorders. Handoko (2014: 200) stated that stress is "a condition of tension that affects one's emotions, thought processes, and condition".

One of problems that will be faced by everyone in their working life is stress that must be overcome, either by employees themselves without the help of others, or with help of other parties. Experts say that stress can arise as a result of pressure or tension that comes from an incompatibility between a person and his environment. (Siagian, 2010:300). It can be concluded that job stress occurs due to an imbalance between the personality characteristics of employees and characteristics of their work and can occur in all working conditions.

\section{Turnover Intention}

Mathis and Jackson (2011: 159) stated that " Turnover intention was a process when employees leave an organization and leave a job position and where the position must be replaced by someone else". Turnover can be in form of resignation, transfer out of an organizational unit, dismissal or death of a member of organization. Culpepper (2011) stated that " turnover intention is the best predictor for identifying turnover behavior that will occur in employees of an organization". The desire to change jobs ( turnover intention ) in employees can be affected by job satisfaction factors at work.

It can be concluded that turnover intention is the desire (intention ) that arises in individuals to do something. Meanwhile, turnover is the cessation of an employee from work voluntarily or moving from work to another workplace.

\section{Research conceptual framework}

Dissatisfied employees will feel a higher workload, increasing the likelihood of experiencing stress. This condition triggers turnover intention and followed by efforts to find another suitable job. Based on this description, conceptual framework of research can be presented in Figure 1.

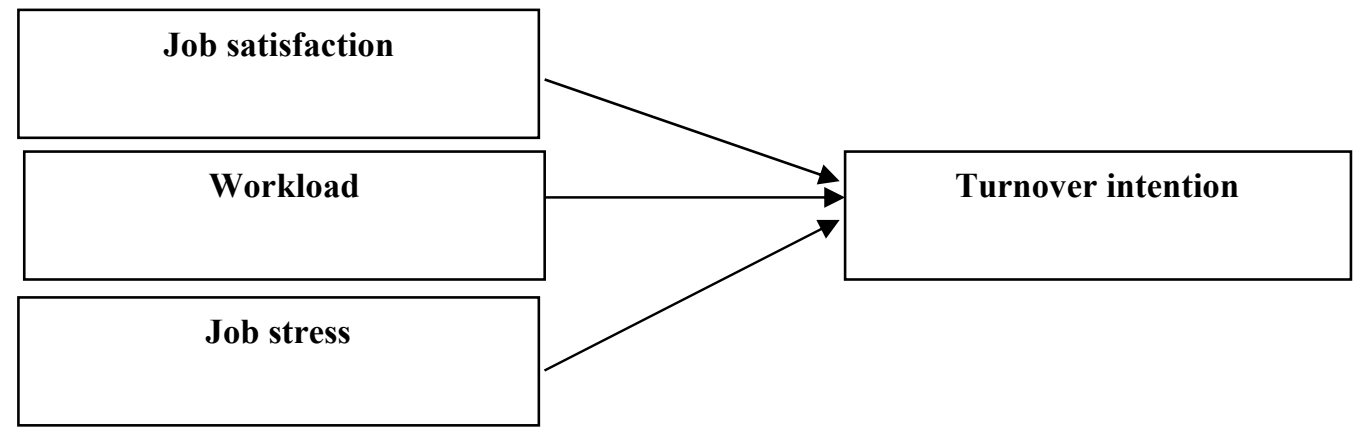

Figure 1. Conceptual Framework

\section{Hypothesis}

Based on formulation of problem, research objectives, research benefits, and theoretical basis, a hypothesis can be stated below.

1. Job satisfaction, workload, and job stress simultaneously have a significant effect on employee turnover intention at CV Sarana Komunikasi Indonesia.

2. Job satisfaction, workload, and job stress partially have a significant effect on employee turnover intention at CV Sarana Komunikasi Indonesia.

3. Work stress has a dominant effect on employee turnover intention at CV Sarana Komunikasi Indonesia.

\section{RESEARCH METHODS}

This study uses a quantitative approach. The quantitative approach is used for hypothesis testing (2015:13). The population is 95 employees. A total of 95 samples were selected using the census technique, in which the entire 
population was used as the research sample.

Data were collected by a questionnaire that had been tested for validity and reliability. This study uses a 5point Likert scale, starting from $1=$ strongly disagree, $2=$ disagree, $3=$ neutral, $4=$ agree and 5 strongly agree. Questionnaires were sent directly to employees assisted by leadership of each division. Filling is done directly at work hours so that all employees can immediately complete filling out the questionnaire and submit it to each division. The data obtained were then analyzed using multiple regression analysis

\section{RESEARCH RESULTS AND DISCUSSION}

The majority of 41 respondents tenure are less than 1 year, followed by 1 to 2 years tenure are 31 respondents, 3 4 years tenure are 15 respondents and 5-7 years tenure are 8 respondents. Based on age, it is known that majority of 51 respondents age are 18-20 years, followed by 21-23 years old are 29 respondents, 24-57 years old are 15 respondents. Analysis of respondents education shows that majority of 55 respondents last education are high school, last education of S1 are 25 respondents and 15 respondents have diploma level education. The majority of 53 respondents are male and remaining 42 are female

\section{Validity and Reliability Test}

The validity test measures the validity level of a questionnaire (Ghozali, 2016). The analysis results show that all of 18 statements have $r_{\text {count }}$ value greater than the $r_{\text {table }}$ and are in accordance with basis for decision making. Therefore, all statements in questionnaire were declared valid.

The reliability test aims to see the results of consistency of respondents' answers (Ghozali, 2016). The results of analysis show that Cronbach alpha value has a value greater than 0.60 . Therefore, all the answers that have been given by respondents are reliable.

\section{Test Results of Multiple Linear Regression Equation Analysis}

Sugiyono (2015: 277) defined multiple linear regression analysis as "Multiple linear regression analysis is used by researchers, if the researcher intends to predict how the situation (up and down) of dependent variable (criteria), if two or more independent variables as predictor factors are manipulated (increase the value)" The results of analysis are shown in following table 1.

Table 1. Test Results of Multiple Linear Regression Equation Analysis

Tabel 4.10: Hasil Analisis Regresi Berganda

\begin{tabular}{|l|r|r|r|r|}
\hline Variables & \multicolumn{1}{|c|}{ T } & \multicolumn{1}{c|}{ Beta } & p-value & \multicolumn{1}{c|}{ Description } \\
\hline Job satisfaction & 2.811 & -.269 & 0.005 & Significant \\
\hline Workload & 3.622 & .390 & 0.000 & Significant \\
\hline Job stress & 2.691 & .268 & 0.008 & Significant \\
\hline Constant $=.246$ & & & \\
Determination coefficient $\left(\mathrm{R}^{2}\right)=0,717$ or $71.7 \%$ & & \\
F-count $=85.768$ \\
P-value $=0.000$
\end{tabular}

Source: Data Processed With SPSS 23.

Based on table 1, the multiple linear regression coefficient equation can be stated as follows:

$\mathrm{Y}=0,216-0,269$ Job satisfaction + 0,361 Workload $+0,233$ Job stress $+\mathrm{e}$

The explanations of the regression equation are below.

1. Constant ( a )

The constant value ( a ) of 0.216 is positive, indicating if the variable (job satisfaction, workload, and job stress) is equal to zero, then the dependent variable ( turnover intention ) is constant. It can be interpreted if the job satisfaction, workload, job stress are zero then turnover intention is a constant of 0.216 .

2. Job Satisfaction on Turnover Intention

The regression coefficient $b_{1}$ for job satisfaction of -0.269 . The value of negative $b_{1}$ showed a relationship of job satisfaction and turnover intention of employees. The job satisfaction increased 1 unit, it will affect the value of variable turnover intention of -0.269 with the assumption that other variables are fixed.

3. Workload on Turnover Intention

The regression coefficient $b_{2}$ for workload is 0.361 . The value of $b_{2}$ positive showed unidirectional relationship variable workloads with turnover intention of employees. The workload increased 1 unit will affect the value of variable turnover intention of 0.361 with the assumption that other variables are fixed.

4. Job stress on Turnover Intention

The regression coefficient $b_{3}$ of job stress is 0.233 . A positive $b$ value ${ }_{3}$ indicates a unidirectional relationship between the job stress variable and employee turnover intention. The job stress is increased by 1 unit will affect the value of variable turnover intention of 0.233 with assumption that other variables are fixed. 


\section{Coefficient of Determination $\left(\mathbf{R}^{\mathbf{2}}\right)$}

This analysis is used to determine the contribution or effect given by independent variable on dependent variable as indicated by a percentage. Table 1 show the value of coefficient of determination $\left(\mathrm{R}^{2}\right)$ is 0.717 or $71.7 \%$. It means that contributions for the effect of job satisfaction, workload and job stress on Turnover intention of employees are 71.7 . The remaining 0,283 or $28.3 \%$ is affected by other variables outside this study.

\section{Hypothesis Test Results}

Based on significance value, it is known that $F_{\text {count }}$ is 85.768 with a significance value of 0.000 . It means that job satisfaction, workload and job stress simultaneously significant effect on turnover intention of employees $\mathrm{CV}$ Sarana Komunikasi Indonesia. Therefore, the hypothesis H1 is accepted.

The partial test results show positive and negative results. The detail explanation is shown below.

1. Job Satisfaction Variable

Table 1 shows that $t_{\text {count }}$ is $2.811>t_{\text {table }}$ of 1.662 at a significance level of $0.005<0.05$. This means that variable job satisfaction partially has a significant effect on turnover intention at CV Sarana Komunikasi Indonesia at negative direction. This research result is consistent with Alfresia (2016) that job satisfaction partially has a negative and significant effect on turnover intention

2. Workload variable

Table 1 shows that $t_{\text {count }}$ is $3.622>t_{\text {table }}$ of 1.662 at a significance level of $0.000<0.05$, this means that workload variable partially has a significant effect on Turnover Intention at CV Sarana Komunikasi Indonesia. This research result is consistent with Dwiningsih (2015) that workload variable partially has a significant effect on Turnover Intention.

3. Job stress variable

Table 1 shows that $\mathrm{t}_{\text {count }}$ is $2.692>\mathrm{t}_{\text {table }}>1.662$ at a significance level of $0.008<0.05$. This means that workload variable partially has a significant effect on turnover intention at CV Sarana Komunikasi Indonesia. This research result is consistent with Herawati (2018) that workload variable partially has a significant effect on turnover intention.

All the three partial effect tests show a significant effect. Therefore, hypothesis $\mathrm{H} 2$ that job satisfaction, workload, and job stress partially have a significant effect on employee turnover intention at CV Sarana Komunikasi Indonesia is accepted.

This dominant hypothesis test is done to prove that workload variable has a dominant effect on turnover

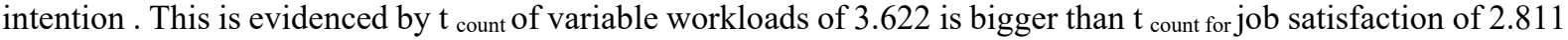
and $t_{\text {count }}$ job stress variable of 2.691 .

\section{CONCLUSIONS AND SUGGESTIONS}

\section{Conclusion}

Based on analysis results, the factors that effecting employee turnover intention are job satisfaction, workload and job stress. The conclusions are stated below.

1. The job satisfaction, workload and job stress variables simultaneously has significant effect on turnover intention of employees at CV Sarana Komunikasi Indonesia.

2. The job satisfaction, workload and job stress variables partially has significant effect on turnover intention of employees at CV Sarana Komunikasi Indonesia.

3. The workload variable has a dominant effect on employee turnover intention in CV Sarana Komunikasi Indonesia

\section{Suggestion}

Based on research results, the suggestion can be stated below.

CV Sarana Komunikasi Indonesia should not burden employees with too much work to improve the job satisfaction variable. The level of employee turnover intention also can be reduced by providing salaries in according with the work. The company can pay more attention to employees by communication and care to show attention and support from superiors. It will make employees feel comfortable at work. Better atmosphere with fellow employees should be improved to create trust between employees.

CV Sarana Komunikasi Indonesia, should provide sufficient time to complete the work of employees, provide good coordination to employees about the duties and authorities of each employee to reduce the level of employee turnover intention. The company should not give overload work to employees.

CV Sarana Komunikasi Indonesia should evaluate superior's behavior to employees in providing work to avoid conflicts between superiors and employees to reduce the level of job stress. Good coordination is also needed to employees regarding company achievements or targets, giving contributions or reciprocity to employees for results that employees have given to company.

This research only examine the employees at CV Sarana Komunikasi Indonesia. Different company may 
shows different results. Therefore, future researchers should examine more companies to improve the generality.

\section{REFERENCE}

Alfresia, Vidya Prischa. 2016. Pengaruh Kepuasan Kerja Dan Komitmen Organisasi Terhadap Turnover Intention Karyawan (Studi Pada PT. Kajima Indonesia). Skripsi, Fakultas Ekonomi Univeritas Negeri Yogyakarta.

Andini, Rita. 2006. Analisis pengaruh kepuasan gaji, kepuasan kerja komitmen organisasional terhadap turnover intention (Studi Kasus Pada Rumah Sakit Roemani Muhammadiyah Semarang). Skripsi, Fakultas Ekonomi Universitas Diponegoro Semarang.

Danang, Sunyoto. 2012. Manajemen Sumber Daya Manusia. Jakarta: PT Buktu Seru.

Dhini, Rama Dhania. 2010. Pengaruh Stres kerja, Beban kerja terhadap Kepuasan kerja. Universitas Muria Kudus. Jurnal Psikologi.

Dwiningsih, Tyas.2015. Pengaruh kepuasan kerja, stres kerja, dan lingkungan kerja terhadap turnover intention karyawan pada CV. ANEKA ILMU SEMARANG. Skripsi, Fakultas Ekonomi Universitas Negeri Semarang

Ghozali, Imam. 2012. Analisis Multivariate SPSS. Semarang : Badan Penerbit Universitas Diponegoro.

Handoko, T. Hani. 2014. Manajemen Pesonalia dan Sumber Daya Manusia, Edisi 2. Yogyakarta:BPFE.

Hasibuan, Melayu. 2014. Manajemen Sumber Daya Manusia, Jakarta: PT Bumi Aksara

Herawati, Jajuk. 2018. Pengaruh Beban Kerja terhadap Turnover Intention Melalui Stress Kerja Sebagai Variabel Intervening (Studi Pada Mirota Batik Yogyakarta). Jurnal UMKM Dewantara Vol. 1 No. 1.

Kasmir. 2016. Manajemen Sumber Daya Manusia (Teori dan Praktik). Depok: PT.Rajagrafindo Persada.

Mangkunegara, Anwar Prabu, 2013. Manajemen Sumber Daya Manusia Perusahaan. Bandung: PT. Remaja Rosdakarya.

Mathis, Robert L. \& H.Jackson. 2011. Human Resource Management (edisis 10). Jakarta: Salemba empat.

Mobley,W. H. 2011. Pergantian Karyawan: Sebab, Akibat dan Pengendalianya, Ahli Bahasa: Nurul Imam. Jakarta: PT Putaka Binaman Pressindo.

Narimawati, Umi,2010. Metodologi Penelitian: Dasar Penyusun Penelitian Ekonomi. Jakarta: Genesis.

Ridlo, I. A.2012 Turnover Karyawan “Kajian Literatur”. Surabaya: Public Health Movement.

Rivai, Veithzal dan Sagala, Ella Jauvani. 2010. Manajemen Sumber Daya Manusia untuk Perusahaan dari Teori ke Praktik. Jakarta: PT. Raja Grafindo.

Robbins, Stephen P. dan Timothy A. Judge. 2015. Perilaku Organisasi. Edisi ke enambelas, Cetakan Pertama, Jakarta :Salemba Empat.

Sari, Rindi Nurlaila. 2014. Pengaruh Kepuasan Kerja dan Komitmen Organisasi Terhadap Turnover Intention (Pada Hotel Ibis Yogyakarta). Skripsi. Fakultas Ekonomi. Universitas Negeri Yogyakarta.

Sugiyono. 2015. Metode Penelitian Kuantitatif, Kualitatif, dan R\&D, Alfabeta, Bandung

Sutrisno, Edy. 2014. Manajemen Sumber Daya Manusia.Jakarta: Penerbit Kencana.

Syafrizal, Dwi Gama. 2016 "Analisis Pengaruh Kepuasan Kerja Terhadap Turnover Karyawan serta Dampaknya Terhadap Kinerja Karyawan (Studi Kasus Pada Hotel Horison Malang)”.Fakultas Ekonomi Universitas Diponegoro

Tarwaka. 2015. Ergonomi Industri Dasar-dasar Pengetahuan Ergonomi dan Aplikasi di Tempat Kerja, Surakarta: Harapan Press 